\title{
HEMATOLOGICAL AND BIOCHEMICAL PARAMETERS IN EDILBAI LAMBS SUBJECTED TO PHARMACOLOGICAL CORRECTION OF HYPOMICROELEMENTOSIS DUE TO BIOGEOCHEMICAL CONDITIONS OF THE LOWER VOLGA REGION
}

\section{V.I. VOROBIOV, D.V. VOROBIOV, E.N. SCHERBAKOVA, I.I. HISMETOV} \author{
sponding author) \\ ORCID: \\ Vorobiov V.I. orcid.org/0000-0002-6669-2850 \\ Vorobiov D.V. orcid.org/0000-0002-4745-8866 \\ The authors declare no conflict of interests \\ Received May 12, 2016
}

Astrakhan State University, 1, pl. Shaumyana, Astrakhan, 414001 Russia, e-mail veterinaria-2011@mail.ru (corre-

Scherbakova E.N. orcid.org/0000-0001-6141-554X

Hismetov I.I. orcid.org/0000-0002-0948-5994

\section{Abstract}

In recent years, latent hypomicroelementoses are increasingly diagnosed in a variety of farm animals, including sheep, in Russia, EU, India and other countries (V.T. Samokhin, 2008). The deficit of selenium, iodine and other vital elements leads to a decrease in hematological parameters and a change in the activity of free radical oxidation and oxidant protection which is a fundamental molecular and cellular mechanism of pathogenesis at various hypomicroelementoses (T.N. Rodionova et al., 2010). The aim of the paper was to comprehensively survey the biogeochemical situation in the Lower Volga region and to evaluate the influence of Se and I deficiency on the physiological status of Edilbai lamb not subjected to pharmacological correction of hypomicroelementoses and after administration of Sedimine ${ }^{\circledR}$ (Russia), a metabolism-regulating organic composition containing Se, I and Fe (III) - dextran stabilizing complex. The probes of soil and water, plants, sheep organs and tissues were sampled according to V.V. Kowalski (1974). Trace elements were detected using atomic absorption spectrometry (M.E. Britske, 1982), selenium was assayed fluorimetrically according to V.V. Yermakov (1975), and iodine was analyzed in thiocyanate-nitrate test. To quantitate the products of lipid peroxidation in lamb blood, we estimated diene conjugates by UV absorption spectra at $233 \mathrm{~nm}$ (Z. Platzer, 1970), malondialdehyde - according to V.S. Buzlama et al. (1997), catalase activity - as per M.L. Korolyuk (1980) and glutathione peroxidase - as described by R. Paglia et al. (1967). Hematological parameters were evaluated according to I.P. Kondrakhin et al. (2004). It was shown that the basic components of terrestrial ecosystems in the Lower Volga region are low in selenium, iodine and cobalt relative to the Black Earth region (V. Kowalski, 1974). In the intact lambs, negative balances of iodine and selenium were found during the observation. Also, hematological parameters and antioxidant defense were low. Blood and metabolic parameters together with the balance of studied microelements indicated a development of latent combined selenium and iodine hypomicroelementosis in the lambs. The use of organic product Sedimine resulted in a significant $(\mathrm{P}<0.05)$ correction of the syndrome of selenium and iodine deficiency in Edilbai lambs. Indeed, the blood levels of selenium increased by $84.0 \%$ and iodine - by $92.7 \%$, the number of erythrocytes was $15.6 \%$ higher, hemoglobin was $7.8 \%$ higher, Se, I, globulins were $8.76 \%$ higher, while the amount of glucose reduced by $33.9 \%$. The diene conjugates diminished by $28 \%$, the malonaldehyde - by $8.2 \%$, the catalase activity increased by $43.3 \%$, and glutathione peroxidase activity was $39.4 \%$ higher. The four month-aged lambs which received Sedimine showed the improvement in all the studied metabolic parameters and the weight gain which exceeded that in the control by $14.4 \%$ $(\mathrm{P}<0.05)$. Additionally, after the Sedimine application the lamb meat was superior to that of the control animals in accumulation of physiologically important $\mathrm{I}, \mathrm{Se}, \mathrm{Mn}, \mathrm{Cu}$, and $\mathrm{Co}$.

Keywords: Edilbai sheep, lambs, biogeochemical provinces, microelements, Se, I, hypomicroelementosis, lipid peroxidation, antioxidant defense, hematological indexes

In recent years, latent complex hypomicroelementoses [5-9], induced by oxidative stress and lack of microelements in the environment [10-13], are increasingly diagnosed in a variety of farm animals in Russia [1-4], EU, India and other countries. This is associated with changes in the activity of free radical oxidation and antioxidant protection $[8,9]$, which serve as fundamental molecular 
and cellular mechanisms of pathogenesis in various endemic diseases [10, 14-16]. As a result, growth and development of animals slows down, integrative functions deteriorate, productivity decreases [1, 17-19]. To prevent and correct the latent forms of hypomicroelementoses, it is necessary to carry out complex studies that include monitoring the biogeochemical situation in the region, assessing the balance of chemical elements in the organism, analyzing the physiological status of animals (including the metabolism of proteins, lipids, carbohydrates, vitamins and minerals) products of lipid peroxidation (LPO) and the activity of antioxidant enzymes.

We are developing a fundamentally novel physiological and biogeochemical concept for the theoretically substantiated selection of deficient microelements necessary for the organism of farm animals [3, 4, 20-22], methods for their application and calculation of dosages using a mathematical analysis of the pharmacokinetics of medications [4, 21]. This approach offers a possibility to prevent and correct the latent forms of combined hypomicroelementoses, to improve general state, reproductive function and productivity of animals.

In the present paper, we for the first time discovered the latent form of combined hypomicroelementosis in Edilbai lambs in the Lower Volga region and showed that the intramuscular injection of the Sedimin ${ }^{\circledR}$ preparation has a positive effect on their physiological state, metabolic processes, hematologic indices, antioxidant system.

The aim of the work was to make a comprehensive study of the biogeochemical situation in the Lower Volga region in connection with the effect of the deficiency of essential microelements on such integrative functions of the Edilbai lambs as growth and development, and also to evaluate the pharmacological correction possibilities of physiological and biochemical status of lambs during hypomicroelementoses.

Tecnjiques. Samples of soils $(0-25 \mathrm{~cm})$, water, plants species, feed, organs and tissues of animals for atomic absorption analysis for the content of trace elements were selected according to V.V. Kovalsky [22] in different areas of the Volgograd and Astrakhan regions.

Tests on 4-month-old Edilbai lambs were carried out in the SPKh Krasnoyarets (Krasnoyarsk Region, Astrakhan Province) in 2014-2015. For the test, two flocks of lambs analogues were selected, 252 heads as control animals, and 268 heads as test animals. Animals were housed in sheepfold sheds and grazed on pasture. In addition to milk, lambs of both groups from the age of 20 days received an equal amount of barley groats. After weaning from the ewes, the lambs ate plant forage with the addition of concentrates according to the norms established in the farm.

Balance test was performed on five control and five test gimmers according to the methodology of the All-Russian Research Institute of Animal Husbandry [23]. Lambs from the test group were injected intramuscularly with the Sedimin ${ }^{\circledR}$ preparation (OOO A-BIO, Russia). Sedimin is certified by the Russian Pharmaceutical Committee (GOSTR № ROSS-RU.PO-96.N10771, preparation No. PVR-2-3.6101651) and is an aqueous mixture of iodine and selenium compounds on the stabilizing basis of the dextran complex. Sedimin was administered at a dose of $1 \mathrm{ml}$ at 20-day age, $2 \mathrm{ml}$ at a 2-month age, $3 \mathrm{ml}$ at a 3-month age and $4 \mathrm{ml}$ at the last month of growing.

Before the test and at the end of survey, animals were weighed. Blood samples were collected before feeding, hematologic indices (number of blood formed elements, hemoglobin, leukoformula), content of $\mathrm{Ca}, \mathrm{P}$ and carotene were determined by I.P. Kondrakhyn [24]. Diene conjugates (DC) were studied by UV absorption spectra at $\lambda=233 \mathrm{~nm}$ [25], the malonic dialdehyde (MDA) 
was assayed by the method of V.S. Buzlama [26]. The catalase activity was studied by the method of M.L. Korolyuk [27], the activity of glutathione peroxidase (GPO) was assessed according to R. Paglia et al. [28]. Microelements in biological samples stored in desiccators were determined by the atomic absorption method [29] using a Hitachi 180-50 spectrophotometer (Japan). The content of selenium was determined fluorimetrically [30], iodine was measured by the rhodanide-nitrite method (GOST 28-548-90) [31].

During statistical processing of the obtained data, the mean $(M)$, the mean error $( \pm m)$, and the correlation coefficients $(C v)$ were calculated. The significance of differences was assessed by the Student's $t$-test at significance level of 0.01-0.05.

Results. In the soil samples from Astrakhan and Volgograd regions, the content of cobalt, selenium, copper, zinc and manganese were on average $8.0 \pm 1.03,0.03 \pm 0.022,15.8 \pm 1.27,45.4 \pm 2.10$ and $142.8 \pm 10.60 \mathrm{mg} / \mathrm{kg}$, respectively. The indicators in water were as follows $(\mu \mathrm{g} / \mathrm{l})$ : Co $-0.7 \pm 0.02, \mathrm{Ni}-0.5 \pm 0.01$, $\mathrm{Se}-0.029 \pm 0.002, \mathrm{Mn}-9.8 \pm 0.70, \mathrm{Zn}-32.1 \pm 2.60, \mathrm{Cu}-4.5 \pm 0.70, \mathrm{I}-$ $1.7 \pm 0.13$. Much more selenium $(0.058 \pm 0.012 \mathrm{mg} / \mathrm{kg})$ was detected in summer $(0.058 \pm 0.012 \mathrm{mg} / \mathrm{kg})$ than in October $(0.021 \pm 0.004 \mathrm{mg} / \mathrm{kg})$.

The amount of microelements in plants correlatively depended on the content in the soil $(r=+0.68)$, the species and physiological characteristics of plants, the climate of a specific region (data not shown), and fluctuated at wide ranges. The iodine content varied from 0.01 to $1.99 \pm 0.06 \mathrm{mg} / \mathrm{kg}$. Attention was drawn to the low amount of cobalt (from traces to $2.2 \pm 0.09 \mathrm{mg} / \mathrm{kg}$ ) and selenium (from 0.01 to $0.07 \pm 0.004 \mathrm{mg} / \mathrm{kg}$ ) in plants, with the exception of astragalus $(\mathrm{Co}-9.6 \pm 0.17, \mathrm{Se}-12.6 \pm 2.18 \mathrm{mg} / \mathrm{kg})$. In the spring and summer months, the accumulation of selenium in plants, similar to the effect observed in soils, was somewhat higher than in the autumn. This is explained by the largest migration of selenium from soil to plants during growing.

Manganese was found in optimal amounts in plants (from $47 \pm 3.12$ to $98 \pm 6.4 \mathrm{mg} / \mathrm{kg}$ ) compared to the content in similar macrophytes from the socalled reference dark fertile soil region [22]. The content of selenium, iodine and cobalt in soils and plants was significantly less than in their analogues from the reference region. The copper in soils and plants (from 2.3 \pm 0.07 to $11.3 \pm 1.4 \mathrm{mg} / \mathrm{kg}$ ) was at the lower limit of normal $[22,32]$. The optimum concentration of selenium in drinking water used by animals and birds has not yet been established. In the reservoirs water of the Volga River delta, the selenium index was $0.019 \pm 0.0006 \mathrm{mg} / \mathrm{l}$.

The lack of a number of chemical elements (Se, I and Co) in soil and plant forages negatively affects the realization of animal genetic program and reduces the physiological capabilities of integrative functions of growth and development in lambs [2-4]. The quantity of selenium in different organs of lambs decreased sequentially in the following order: liver $>$ muscles $>$ spleen $>$ bone tissue $>$ lungs $>$ wool $>$ blood $>$ kidneys $>$ small intestinal wall. The cobalt order looked like this: liver $>$ bone tissue $>$ spleen $>$ intestinal wall $>$ wool $>$ kidneys $>$ blood $>$ muscles. Considering the large volume of muscles in sheep, muscle tissue, as well as liver, can be considered a depot of cobalt and other studied trace elements. The decreasing series of manganese, copper, zinc and iodine were similar to each other with very little difference. For example, amount of copper $(9.5 \pm 0.07$ $\mathrm{mg} / \mathrm{kg}$ ) in small intestine wall was almost the same as in spleen, wool, lungs and kidneys. According to the zinc content, the intestinal wall $(155 \pm 13 \mathrm{mg} / \mathrm{kg})$ was

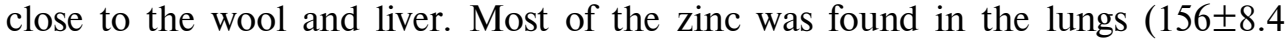
$\mathrm{mg} / \mathrm{kg}$ ), where this element is concentrated, entering the carbonic anhydrase which regulates respiratory function in animals. 
Comparing the data on the accumulation of trace elements in organs and tissues of Edilbai lambs with similar characteristics in young sheep in the reported of other authors [1-3, 33-35], it can be noted that the level of I, Co and Se in our experiments was relatively low and correlated with a low content of these trace elements in plants of the Lower Volga region $(r=+0.74)$.

After weaning from the ewes, the average daily balance of iodine and selenium in lambs, completely transferred to plant and concentrated forage, was negative (Table 1). The balance of cobalt was of a tense nature and approaching zero balance. The balance of $\mathrm{Mn}, \mathrm{Cu}$ and $\mathrm{Zn}$ was positive, the organism of lambs did not lack these elements, which was due to their relatively high content in forage.

1. Balance of microelements $(\mathrm{mg})$ in Edilbai lambs $(n=10, M \pm m$; SPKh Krasnoyarets, Krasnoyarsk Region, Astrakhan Province, 2014-2015)

\begin{tabular}{l|c|c|c|c|c}
\hline \multirow{2}{*}{ Trace element } & \multirow{2}{*}{ Input with forage } & \multicolumn{3}{|c|}{ Excreted } & \multirow{2}{*}{ Assimilated (balance) } \\
\cline { 3 - 5 } & & with feces & with urine & total & \\
\hline $\mathrm{Co}$ & $0,31 \pm 0,04$ & $0,28 \pm 0,01$ & $0,02 \pm 0,003$ & $0,30 \pm 0,01$ & $+0,01 \pm 0,003$ \\
$\mathrm{Se}$ & $0,69 \pm 0,03$ & $0,73 \pm 0,02$ & $0,03 \pm 0,005$ & $0,76 \pm 0,02$ & $-0,07 \pm 0,003$ \\
$\mathrm{I}$ & $0,10 \pm 0,08$ & $0,14 \pm 0,04$ & $0,04 \pm 0,006$ & $0,18 \pm 0,04$ & $-0,08 \pm 0,005$ \\
$\mathrm{Cu}$ & $5,97 \pm 0,11$ & $5,82 \pm 0,95$ & $0,06 \pm 0,002$ & $5,88 \pm 0,72$ & $+0,09 \pm 0,006$ \\
$\mathrm{Mn}$ & $68,0 \pm 1,34$ & $63,2 \pm 3,15$ & $0,11 \pm 0,007$ & $63,31 \pm 2,07$ & $+4,69 \pm 0,270$ \\
$\mathrm{Zn}$ & $29,6 \pm 0,09$ & $22,5 \pm 1,96$ & $0,21 \pm 0,009$ & $22,71 \pm 1,35$ & $+6,83 \pm 0,050$ \\
\hline
\end{tabular}

The results of balance tests, along with biogeochemical monitoring of the environment and the content of trace elements in organs and tissues, allow us to state the deficiency of selenium and iodine in the Edilbai lambs that suggests the necessity of using Se and I preparations in the Lower Volga region. However, for the final decision necessitates estimation of physiological status of animals, including hematological indices, the degree of free radical oxidation and antioxidant protection.

The antioxidant mechanisms induce enzymatic and non-enzymatic processes. Antioxidants are involved in the regulation of peroxidation as components of an unite system that includes a number of enzymes, low molecular weight compounds, physiologically active substances of protein and lipid nature, including vitamins, $\mathrm{Ca}, \mathrm{Se}, \mathrm{Fe}, \mathrm{Zn}$ and $\mathrm{Cu}$, and possibly other macro- and microelements that are part of antioxidant enzymes or can activate enzymes [36]. It is known that cation radicals of selenium, manganese, zinc, copper, molybdenum, cobalt, and iron-sulfur clusters can participate in the initiation of free radical oxidation $[3,4,15,37]$.

Intramuscular application of iodine and selenium, lacking in the organism of growing lambs, led to an increase in hematopoiesis (Table 2). In the lambs from the test group, the erythrocytes increased by $15.6 \%$, hemoglobin increased by $7.8 \%$, selenium - by $84.0 \%$, iodine - by $92.7 \%$, total protein by $4.44 \%$, globulins - by $8.76 \%$ if compared to the same parameters in the control group $(\mathrm{P}<0.05)$. The parameters of the carbonate blood buffer in lambs receiving Sedimin were $34.9 \%$ above the control $(\mathrm{P}<0.05)$. In the animals from the test group, blood glucose level was $33.9 \%$ lower than that in the control group. The amount of total protein of the globulin fraction containing selenium was also slightly higher in lambs receiving Sedimin than in the control animals $(\mathrm{P}<0.05)$.

At weaning, all physiological and biochemical indicators of lambs' blood, which were pharmacologically corrected for microelement deficiencies, reached a physiological norm. The number of DC decreased by $28.0 \%$, MDA by $8.2 \%$, the activity of antioxidant enzymes increased (by $43.3 \%$ for catalase, and by $39.4 \%$ for GPO), while the glucose content decreased by $39.9 \%$ relatively to the beginning of the test. The obtained data testifies to the metabolism activation 
in animals of the test group and disappearance of the signs of latent combined hypomicroelementosis, which agrees with the results of other studies [33].

In control lambs, the blood concentration of diene conjugates compared to that at the beginning of the test significantly increased by $17.60 \%$, while malonic dialdehyde was only $8.06 \%$ higher (the blood level of MDA, as one of the final products of free radical oxidation, is not subjected to significant fluctuations).

2. Blood parameters in Edilbai lambs injected intramuscularly with the Sedimin ${ }^{\circledR}$ $(M \pm m$; SPKh Krasnoyarets, Krasnoyarsk Region, Astrakhan Province, 20142015)

\begin{tabular}{|c|c|c|c|c|}
\hline \multirow{2}{*}{ Parameter } & \multicolumn{2}{|c|}{ Test group $(n=5)$} & \multicolumn{2}{|c|}{ Control group $(n=5)$} \\
\hline & beginning of the $t$ & end of the te & ning of the & end of the test \\
\hline $\begin{array}{l}\text { Erythrocytes, million } / \mu 1 \\
\left(\times 10^{12} / 1\right)\end{array}$ & $7.52 \pm 0.28$ & $8.69 \pm 0.57 *$ & $7.62 \pm 0.36$ & $8.01 \pm 0.56$ \\
\hline Hemoglobin, g/l & $81.14 \pm 4.12$ & $88.27 \pm 6.38^{*}$ & $82.9 \pm 3.19$ & $81.5 \pm 2.75$ \\
\hline Leukocytes, thousand $/ \mu 1$ & $845+106$ & $876+071$ & $815+078$ & $826+078$ \\
\hline $\begin{array}{l}\left(\times 10^{9} / 1\right) \\
\text { Total protein, } \mathrm{g} / 1\end{array}$ & $\begin{array}{r}8.45 \pm 1.96 \\
69.70 \pm 4.16\end{array}$ & $72.80 \pm 6.09 *$ & $\begin{array}{r}8.15 \pm 0.18 \\
68.71 \pm 3.55\end{array}$ & $\begin{array}{r}8.26 \pm 0 . / 8 \\
67.21 \pm 3.33\end{array}$ \\
\hline Albumin, g/l & $23.60 \pm 1.88$ & $24.50 \pm 1.36$ & $24.30 \pm 1.64$ & $23.72 \pm 2.51$ \\
\hline Globulin, g/l & $36.50 \pm 2.35$ & $39.70 \pm 2.15^{*}$ & $36.50 \pm 3.15$ & $35.83 \pm 1.78$ \\
\hline Glucose, $\mu \mathrm{mol} / 1$ & $3.01 \pm 0.08$ & $1.99 \pm 0.07^{*}$ & $2.98 \pm 0.06$ & $3.55 \pm 0.28^{*}$ \\
\hline Diene conjugates, $\mu \mathrm{mol} / 1$ & $4.11 \pm 0.17$ & $2.96 \pm 0.17^{*}$ & $3.97 \pm 0.56$ & $4.67 \pm 0.19^{*}$ \\
\hline Malonic dialdehyde, $\mu \mathrm{mol} / \mathrm{l}$ & $0.76 \pm 0.06$ & $0.69 \pm 0.02$ & $0.62 \pm 0.16$ & $0.67 \pm 0.07$ \\
\hline $\begin{array}{l}\text { Glutathione peroxidase, } \\
\mathrm{mmol} \mathrm{G-SH} \cdot 1^{-1} \cdot \min ^{-1} \cdot 10^{3}\end{array}$ & $5.92 \pm 0.08$ & $8.25 \pm 0.06^{*}$ & $5.77 \pm 0.42$ & $4.01 \pm 0.54^{*}$ \\
\hline Catalase, $\mu \mathrm{mol} / \mathrm{ml}$ & $3.88 \pm 0.13$ & $5.56 \pm 0.27 *$ & $3.86 \pm 0.29$ & $2.88 \pm 0.02 *$ \\
\hline Alkaline reserve, vol. $\% \mathrm{CO}_{2}$ & $41.80 \pm 2.06$ & $56.42 \pm 1.17^{*}$ & $42.90 \pm 4.15$ & $32.30 \pm 1.43^{*}$ \\
\hline Selenium, $\mu \mathrm{g} / 1$ & $38.20 \pm 1.44$ & $60.30 \pm 1.06^{*}$ & $37.90 \pm 1.06$ & $29.50 \pm 1.16^{*}$ \\
\hline Iodine, $\mathrm{mg} / \mathrm{l}$ & $0.41 \pm 0.02$ & $0.52 \pm 0.02 *$ & $0.44 \pm 0.05$ & $0.39 \pm 0.01^{*}$ \\
\hline
\end{tabular}

The blood catalytic activity in control lambs at the end of the test was $25.5 \%$ less than at the beginning of the test. Blood glutathione peroxidase reduced its activity by $30.6 \%(\mathrm{P}<0.05)$ to the 4 -month age compared to the beginning of the test. This is due to the beginning of the use of plant forages, poorly provided with selenium, iodine and cobalt which are part of antioxidant enzymes (i.e. selenium is necessary for GPO activity, zinc, copper, manganese are necessary for superoxide dismutase) and can activate catalase activity [4, 36]. There was a decrease in the amount of selenium, iodine, and acid capacity of blood in lambs from the control group at the end of the test compared to its onset, indicating an increasing acidic stress which predetermines latent hypomicroelementosis. In the organism, LPO products began to accumulate while reducing the activity of antioxidant enzymes. All this led to depletion of cells antioxidant protection, development of the syndrome of latent hypomicroelementosis, and a decrease in integrative functions of growth and development of young animals.

At the 4-month age, the body weight of lambs was $35.9 \pm 2.23 \mathrm{~kg}$ in the control flock, and $44.1 \pm 3.11 \mathrm{~kg}$ in the test flock, or $14.4 \%$ more. The organs and tissues of the lambs from the test group were better provided with physiologically important trace elements (by 15-36 \%) than in the control animals, which agrees with the data of foreign authors who studied the content of trace elements in organs and tissues of the lambs of Landsherp German merino [18, 34, 35]. In 4-month-old lambs, the ratio of the meat part of the carcass, which is a functional production feature of the Edilbai sheep and serves as the breed genetic parameter and the functional norm for Edilbai sheeps [33], was $78.6 \%$ in control and $87.0 \%$ in the test lambs.

Thus, the low accumulation of iodine and selenium in the main components of ecosystems in the Lower Volga, along with revealed low hematological parameters, high content of lipid peroxidation products (diene conjugates, malonic dialdehyde) and low activity of antioxidant enzymes (catalase, glutathione 
peroxidase) in growing Edilbai lambs in combination with the results of balance test, indicate the development of latent combined hypomicroelementosis in the animals. Intramuscular injection of Sedimin ${ }^{\circledR}$ containing selenium and iodine improves the physiological state of growing lambs, normalizes metabolism and hematological parameters, stabilizes activity of antioxidant system and provides a reliable increase in body weight by $14.4 \%(\mathrm{P}<0.05)$ compared to control.

\section{REFERE N C ES}

1. Samokhin V.T. Materialy VI Mezhdunarodnoi biogeokhimicheskoi shkoly AGTU «Biogeokhimiya $v$ narodnom khozyaistve: fundamental'nye osnovy noosfernykh tekhnologii» [Proc. VI Int. Biogeochtmical School AGTU «Biogeochemisry: fundamental aspects of noospherebased technologies»]. Astrakhan', 2008: 159-160 (in Russ.).

2. Rodi o n o v a T.N., A n t i p o v V.A., L a z a re v V.G. Farmakologiya selenoorganicheskogo preparata DAFS-25 $i$ ego ispol'zovanie $v$ zhivotnovodstve $i$ veterinarii [DAFS-25, a seleniumcontacting composition: pharmacological parameters and application in animal husbandry and veterinary medicine]. Saratov, 2010 (in Russ.).

3. Vor o b'e v V.I., Vo ro b'e v D.V. Zhurnal fundamental'nykh i prikladnykh issledovanii, 2010, 1(30): 12-18 (in Russ.).

4. Vorob'ev D.V., Vorob'ev V.I., Kutepov A.Yu., Polkovnichenko A.P. Fiziologicheskii status $i$ ego korrektsiya $u$ zhvachnykh, vseyadnykh zhivotnykh $i$ ptits $v$ biogeokhimicheskikh usloviyakh regiona Nizhnei Volgi [Physiological parameters and their improving in ruminants, other mammalians and poultry under biogeochemical conditions of Lower Volga]. St. Petersburg, 2011 (in Russ.).

5. Alhidary I.A., Shin i S., A l J a s s i m R.A.M., G a u g ha n J.B. Effect of various doses of injected selenium on performance and physiological responses of sheep to heat load. Journal of Animal Science, 2012, 90(9): 2988-2994 (doi: 10.2527/jas.2011-4908).

6. Humann-Ziehanka E., Renkob K., Muellerc A. S., Roehriga P., Wolfse na J., Gantera M. Comparing functional metabolic effects of marginal and sufficient selenium supply in sheep. Journal of Trace Elements in Medicine and Biology, 2013, 27(4): 380-390 (doi: 10.1016/j.jtemb.2013.03.003).

7. S e ji a n V., S i ngh A.K., S ah o o a nd S.A., N aqvi M.K. Effect of mineral mixture and antioxidant supplementation on growth, reproductive performance and adaptive capability of Malpura ewes subjected to heat stress. Journal of Animal Physiology and Animal Nutrition, 2014, 98(1): 72-83 (doi: 10.1111/jpn.12037).

8. Faix S., Faixova Z., Boldizarova K., Javorsky P. The effect of long-term high heavy metal intake on lipid peroxidation of gastrointestinal tissue in sheep. Vet. Med. - Szech, 2005, 50(9): 401-405.

9. Mohebbi-Fani M., Mirzaei A., Nazifi S., Shabbooie Z. Changes of vitamins $\mathrm{A}, \mathrm{E}$, and $\mathrm{C}$ and lipid peroxidation status of breeding and pregnant sheep during dry seasons on medium-to-low quality forages. Tropical Animal Health and Production, 2012, 44(80): 259-265 (doi: 10.1007/s11250-011-0012-1).

10. Heidarpour M., Mohri M., Borji H., Moghaddas E. Oxidant/antioxidant balance and trace elements status in sheep with liver cystic echinococcosis. Original Article Comparative Clinical Pathology, 2013, 22: 1043-1049 (doi: 10.1007/s00580-012-1523-5).

11. Xina G.S., Longa R.J., Guob X.S., Irvineb J., D ingb L.M., D ingb L.L., $\mathrm{S}$ h a ng a Z.H. Blood mineral status of grazing Tibetan sheep in the Northeast of the Qinghai-Tibetan Plateau. Livestock Science, 2011, 136: 102-107.

12. S a le ha M.A., Al-S a la hy b M.B., S a nou si c S.A. Corpuscular oxidative stress in desert sheep naturally deficient in copper. Small Ruminant Research, 2008, 80: 33-38.

13. Esmaeilnejada B., Tavassolia M., Asri-Rezaeib S., Dalir- Naghadehb B., Malekinejadc H., Jalilzadeh-Aminb G., Arjmanda J., Golabia M., $\mathrm{H}$ a j i p o u r a N. Evaluation of antioxidant status, oxidative stress and serum trace mineral levels associated with Babesia ovis parasitemia in sheep. Veterinary Parasitology, 2014, 1-2: 38-45 (doi: 10.1016/j.vetpar.2014.07.005).

14. Chadio St.E., Kot sa mpas i B.M., Me negat os J.G., Zervas G.P., Ka logia $\mathrm{n} n$ is D.G. Effect of selenium supplementation on thyroid hormone levels and selenoenzyme activities in growing lambs. Biological Trace Element Research, 2006, 109(2): 145-154 (doi: 10.1385/BTER:109:2:145).

15. Q i n Sh., G a o J., H u a ng K. Effects of different selenium sources on tissue selenium concentrations, blood GSH-Px activities and plasma interleukin levels in finishing lambs. Biological Trace Element Research, 2007, 116(1): 91-102 (doi: 10.1007/BF02685922).

16. Bolanda T.M., B rophya P.O., Callan a J.J., Quinna P.J., Nowakowskib P., $\mathrm{Crosby}$ T.F. The effects of mineral supplementation to ewes in late pregnancy on colostrum 
yield and immunoglobulin G absorption in their lambs. Livestock Production Science, 2005, 97(2-3): 141-150 (doi: 10.1016/j.livprodsci.2005.03.004).

17. Koy u cu M., Yerlik a a H. Short sommunication effect of selenium-vitamin E injections of ewes on reproduction and growth of their lambs. South African Journal of Animal Science, 2007, 37(4): 233-236 (doi: 10.4314/sajas.v37i4.4095).

18. Kumar N., Garg A.K., Mudgal V., Dass R.Sh., Chaturvedi V.K., Varsh $n$ e y V.P. Effect of different levels of selenium supplementation on growth rate, nutrient utilization, blood metabolic profile, and immune response in lambs. Biological Trace Element Research, 2008, 126(1): 44-56 (doi: 10.1007/s12011-008-8214-8).

19. Kumara N., Garga A.K., Dassa R.S., Chaturvedib V.K., Mudgala V., V a rs h n y c V.P. Selenium supplementation influences growth performance, antioxidant status and immune response in lambs. Animal Feed Science and Technology, 2009, 153(1-2): 77-87 (doi: 10.1016/j.anifeedsci.2009.06.007).

20. V o r o b'e v D.V. Fundamental'nye issledovaniya, 2011, 11: 402-406 (in Russ.).

21. S o lov'e v V.N., Fi r s o v A.A., Filov V.A. Farmakokinetika [Pharmacokinetics]. Moscow, 1980 (in Russ.).

22. K o v a l's k i i V.S. Geokhimicheskaya ekologiya [Geochemical ecology]. Moscow, 1974 (in Russ.).

23. To m m e M.F. Metodika izucheniya perevarimosti kormov $i$ ratsionov [Feeds and diets: methods to study digestibility]. Moscow, 1965 (in Russ.).

24. Kondrakhin I.P., Arkhipov A.V., Levchenko V.I., Ta lanov G.A., Fro lov A.A., N ovikov V.E. Metody veterinarnoi klinicheskoi laboratornoi diagnostiki [Clinical diagnostics in veterinary medicine]. Moscow, 2004 (in Russ.).

25. Platser Z., Vidlakova M., Kupila L. Chekhosl. med. obzor, 1970, 16(1): 30-34 (in Russ.).

26. Buzla ma V.S., Titov Yu.T., Vost ro ilova G.A., Vas h chenko Yu.E. Ekspressbiotest. Biologicheskii monitoring system [Express biotest. Biomonitoring in different systems]. Voronezh, 1997 (in Russ.).

27. K o r o ly u k M.A. Laboratornoe delo, 1980, 1: 40-59 (in Russ.).

28. P a g 1 i a R., Valentine J. Definition of a glutathione peroxidases. Lab. Clin. Med., 1967: 158-169.

29. B rits k e M.E. Atomno-absorbtsionnyi spektrokhimicheskii analiz [Atomic absorption spectroscopy]. Moscow, 1982 (in Russ.).

30. E r m a k o v V.V. Vitaminy. Biokhimiya vitamina E i selena, 1975, 8: 142-146 (in Russ.).

31. Yavi ch P.A., Kak he t e $\mathrm{lidz}$ e M.B., C hu radze L.I. Issledovaniya $v$ oblasti estestvennykh nauk, 2014, 1. Available http://science.snauka.ru/2014/01/6585. No date (in Russ.).

32. M a t v e e v A.M., P a v lov s k i i V.A., P ro kho rov a N.V. Ekologicheskie osnovy akkumulyatsii tyazhelykh metallov sel'skokhozyaistvennymi rasteniyami [Ecological aspects of heavy metal accumulation in cultivated crops]. Samara, 1997 (in Russ.).

33. K a n a p i n K. Edil'baevskaya ovtsa [Edilbay sheep]. Almaty, 2009 (in Russ.).

34. B e 11 of G., Most E., Palla u f J. Concentration of copper, iron, manganese and zinc in muscle, fat and bone tissue of lambs of the breed German Merino Landsheep in the course of the growing period and different feeding intensities. Journal of Animal Physiology and Animal Nutrition, 2007, 91(3-4): 100-108 (doi: 10.1111/j.1439-0396.2006.00648.x).

35. Humann-Ziehanka E., Gantera M., Hennig-Paukaa I., Binderb A. Trace mineral status and liver and blood parameters in sheep without mineral supply compared to local roe deer (Capreolus capreolus) populations. Small Ruminant Research, 2008, 75(2-3): 185-191 (doi: 10.1016/j.smallrumres.2007.10.006).

36. L a n k i n V.Z., T i k h a z e A.K., B e l e n k o v Yu.N. Svobodnoradikal'nye protsessy v norme i pri patologicheskikh sostoyaniyakh [Free radicals in health and disease]. Moscow, 2001 (in Russ.).

37. Che ng J., M a H., F a n C., Zhang Z., J i a Z., Z hu X., W a ng L. Effects of different copper sources and levels on plasma superoxide dismutase, lipid peroxidation, and copper status of lambs. Biological Trace Element Research, 2011, 144(1): 570-579 (doi: 10.1007/s12011-011-9065-2). 